\title{
A Syrian man with abdominal pain
}

\author{
Mary Chughtai, ${ }^{1}$ Rigo Hoencamp, ${ }^{1,2,3}$ Maarten Bronkhorst ${ }^{4}$
}

${ }^{1}$ Surgery, Leids Universitair Medisch Centrum, Leiden, The Netherlands

${ }^{2}$ Surgery, Alrijne Ziekenhuis Locatie Leiderdorp, Leiderdorp, The Netherlands

${ }^{3}$ Surgery, Nederland Ministerie van Defensie, Den Haag, The Netherlands

${ }^{4}$ Surgery, Medisch Centrum Haaglanden, Den Haag, The Netherlands

\section{Correspondence to Mr Rigo Hoencamp, r.hoencamp@lumc.nl}

Accepted 5 May 2017

\begin{abstract}
SUMMARY
A 32-year-old man presented with progressive abdominal pain, nausea and vomiting after swallowing a packet of dollar bills, his entire money savings, during his journey to Europe as a refugee. Subsequent imaging confirmed the presence of a foreign body in his stomach, which required surgical intervention to be removed. This is one of many cases that illustrate the hopeless circumstances people in the Middle-Eastern warzone are currently facing.
\end{abstract}

\section{CASE PRESENTATION}

A 32-year-old Syrian man, with no relevant medical history, presented at our emergency department with severe acute abdominal pain. On arrival of the patient at our emergency department, standard Methicillin-resistant Staphylococcus aureus (MRSA) contact precautions were taken ${ }^{1}$ until the patient's MRSA screening test results were negative. Communicating with the patient was challenging due to a language barrier. The patient spoke Levantine Arabic exclusively, whereas none of the present doctors did. This posed a problem for both the patient and the healthcare staff. Eventually, an Arabic-speaking translator was arranged, who was able to communicate with the patient. Patient history revealed that the patient had swallowed a packet of dollar bills on his way to Europe as a Syrian refugee. The money comprised all of his savings, which he had swallowed fearing burglary during his journey. His symptoms included abdominal pains, primarily located in the epigastric region, persistent nausea and vomiting. During physical examination, a cachectic man was seen with obvious abdominal tenderness. Furthermore, old traumatic amputations of the third and fourth digits of his left hand were noticed. This had been the result of a bomb blast, as we were told by the patient. An abdominal X-ray and a CT scan were performed and revealed the ingested foreign body located in the stomach (figure 1), without signs of perforation and obstruction. Standard blood tests, including a complete blood count and blood chemistry, and a standard urine analysis were carried out as part of a routine medical exam, without any abnormalities. Extraction of the foreign body via gastroscopy was unsuccessful; therefore, we proceeded to a median laparotomy and subsequently a gastrotomy (figure 2). This resulted in the successful removal of a packet of rolled dollar bills in a partially torn rubber packaging. The packet contained 26 dollar bills with a total value of US\$1807 (figure 3). The bills were intact and in good condition, despite

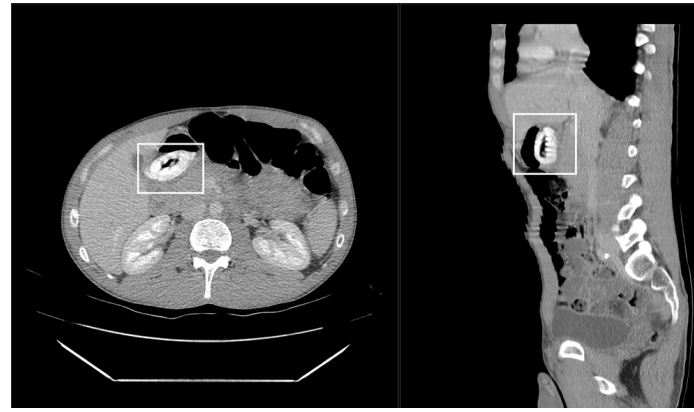

Figure 1 An abdominal CT scan revealed the presence of a foreign body in the pyloric antrum. A transverse and a sagittal section are shown. There were no signs of stomach perforation or pneumoperitoneum.

the immersion in stomach acid, and were returned to the patient postoperatively. The patient was clearly relieved on receiving his money back, as he had been concerned that his money might have been taken away from him after surgery.

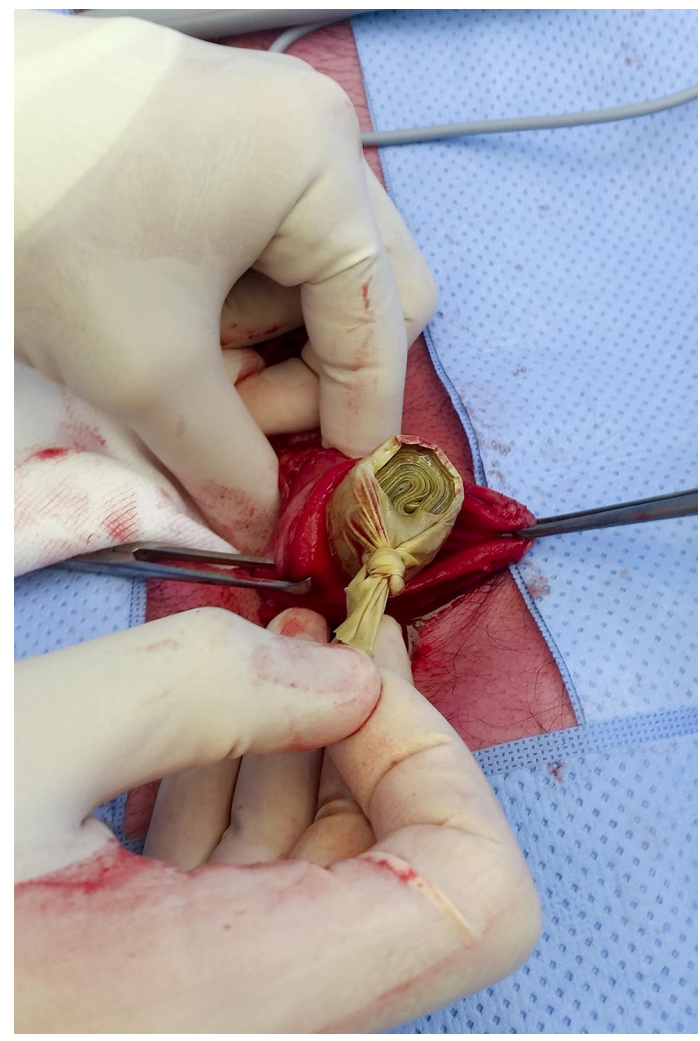

Figure 2 A median laparotomy and a subsequent gastrotomy were performed. Inside the stomach we found part of a torn rubber glove in which rolled-up dollar bills were visible. 


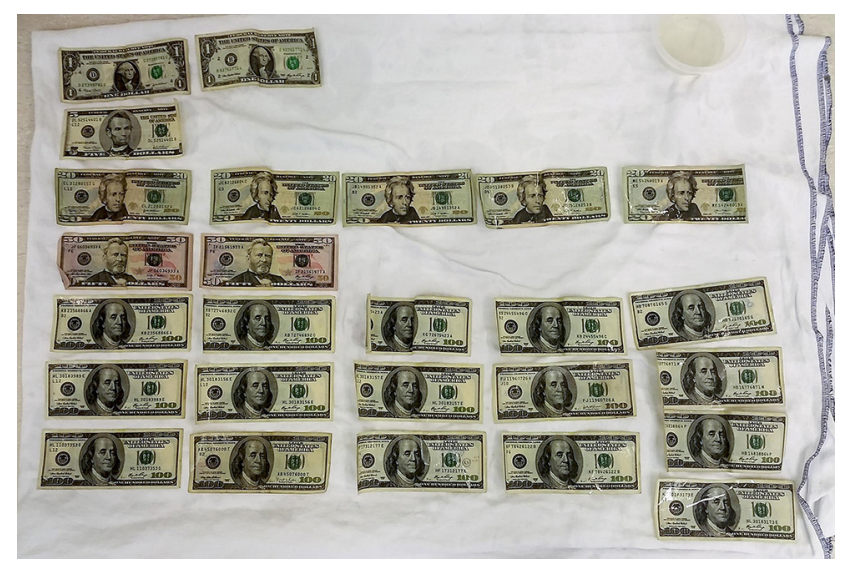

Figure 3 The package contained 26 intact dollar bills with a total worth of US\$1807.

During the stay of our patient, no psychiatric assessment was carried out; however, it is something that could be considered in similar cases in the future. The patient had a comfortable postoperative recovery and was discharged from the hospital in good health. During his recovery, social services were involved and evaluated his plans after discharge. We were informed that the patient was planning on travelling to Germany and temporarily stay with acquaintances who were already living there.

\section{GLOBAL HEALTH PROBLEM LIST}

$\checkmark$ Refugees

- War

- Forced displacement

- Civil vulnerability

- Habitat destruction

\section{GLOBAL HEALTH PROBLEM ANALYSIS}

There are more than 65 million forcibly displaced people worldwide today. Out of these people, 21.3 million are refugees. This is the highest it has been in human history, even more than during and after World War II. ${ }^{2}$ The largest number of refugees ( 4.5 million) is of Syrian Arab Republican origin, ${ }^{23}$ indicating the relevance of our described case.

Moreover, health consequences in forcibly displaced people and refugees are usually more severe due to population displacement, food scarcity and the lack of basic health services. Higher mortality and morbidity rates are usually observed, which can effectively be decreased by providing adequate food ratios, clean water and sanitation. Furthermore, infectious disease control should also be taken into consideration, as was done in our described case. ${ }^{4}$

\section{Patient's perspective}

"It is very common for refugees to swallow their money or valuable belongings before their journey to another place or country, fearing burglary and theft."

\section{Learning points}

- This case report illustrates the relevance of the current desperate situation in Syria.

- Even though medical physicians cannot change these circumstances on a global scale, we can play a role in creating awareness surrounding this topic nevertheless and recognising its social importance.

- Ideally, internationally joined efforts could provide optimal support to vulnerable refugees seeking help.

This patient's case is one of many that illustrate the hopeless circumstances and fears people in the Middle-East are currently facing. Even though medical physicians cannot change these circumstances on a global scale, we can play a role in creating awareness surrounding this topic nevertheless and recognising its social importance. It is our duty as doctors and healthcare workers to provide the best care to vulnerable refugees who are desperate for safety.

Contributors Conception and design: $\mathrm{MC}, \mathrm{RH}$ and MB. Acquisition of data: $\mathrm{RH}$ and $\mathrm{MB}$. Interpretation of data: $\mathrm{MC}, \mathrm{RH}$ and $\mathrm{MB}$. Drafting the manuscript: $\mathrm{MC}$ and RH. Revision of the manuscript: RH and MB. Approval of the final version of the manuscript: $\mathrm{MC}, \mathrm{RH}$ and $\mathrm{MB}$.

Competing interests None declared.

Patient consent Consent obtained from next of kin.

Provenance and peer review Not commissioned; externally peer reviewed.

(C) BMJ Publishing Group Ltd (unless otherwise stated in the text of the article) 2017. All rights reserved. No commercial use is permitted unless otherwise expressly granted.

\section{REFERENCES}

1 Siegel JD, Rhinehart $\mathrm{E}$, Jackson $\mathrm{M}$, et al. Management of multidrug-resistant organisms in health care settings, 2006. Am J Infect Control 2007;35(10 Suppl 2):S165-S193.

2 UNHCR. Global trends forced displacement in 2015. $2015 \mathrm{https}: / / \mathrm{s} 3$.amazonaws. com/unhcrsharedmedia/2016/2016-06-20-global-trends/2016-06-14-Global-Trends2015.pdf.

3 Devi S. Syria's health crisis: 5 years on. Lancet 2016;387:1042-3.

4 Toole MJ, Waldman RJ. The public health aspects of complex emergencies and refugee situations. Annu Rev Public Health 1997;18:283-312.

Copyright 2017 BMJ Publishing Group. All rights reserved. For permission to reuse any of this content visit

http://group.bmj.com/group/rights-licensing/permissions.

BMJ Case Report Fellows may re-use this article for personal use and teaching without any further permission.

Become a Fellow of BMJ Case Reports today and you can:

- Submit as many cases as you like

- Enjoy fast sympathetic peer review and rapid publication of accepted articles

- Access all the published articles

- Re-use any of the published material for personal use and teaching without further permission

For information on Institutional Fellowships contact consortiasales@bmjgroup.com

Visit casereports.bmj.com for more articles like this and to become a Fellow 